\title{
Research on Incorruptible Culture in the Cultivation of Medical Ethics of Students in Medical Colleges
}

\author{
Wen $\mathrm{Hu}$ \\ Department of Psychology \\ Gannan Medical University \\ Ganzhou, Jiangxi, China 341000
}

\author{
Yu Zhao \\ Department of Psychology \\ Gannan Medical University \\ Ganzhou, Jiangxi, China 341000
}

\begin{abstract}
In order to expose the status quo of medical ethics of students in medical colleges, 2,916 freshmen are surveyed through questionnaires, and the statistic analysis made on the survey results show, the results of some problems are not satisfactory. The results can be used to direct the medical ethics cultivation of students in medical colleges, and the medical ethics education can be carried out according to specialties and grades so as to cultivate the medical ethics quality of students in the atmosphere of incorruptible culture in colleges.
\end{abstract} quality

Keywords-medical ethics; incorruptible culture; humanistic

\section{INTRODUCTION}

Doctor-patient relationship is a focus attracting most eyeballs of the society, and higher requirements are raised to medical workers, who are not only therapists and caregivers but also act as messengers and health knowledge disseminators, facing such a situation, new requirements are raised to medical colleges which cultivate medical workers as well, and it is necessary to strengthen the education of humanistic quality and correct values as well as medical ethics on medical students. The incorruptible culture environment in colleges plays an active role in cultivating the lofty medical ethics of medical students. In order to overall master the status quo of medical ethics of medical students in colleges, through questionnaires, 2916 freshmen are surveyed on knowledge, cognition and problems relative to medical ethics.

\section{OBJECT AND METHOD}

\section{A. Research Object}

2,916 medical and non-medical students out of freshmen of grade 2016 in a college are survey with their names untold, 3,000 questionnaires are released, 2,916 of which are returned, and the return rate is $97.2 \%$, the participants include 1,488 medical students and 1,428 non-medical students.

\section{B. Research Method}

SPSS19.0 is adopted for data analysis with the results analyzed via descriptive statistics

\section{RESULTS}

\section{A. Knowledge about Medical Ethics of Students in Medical Colleges}

Items 1-10 in the questionnaire are to survey the students' knowledge and understanding of medical ethics and medical ethics phenomena. The overall survey results are optimistic. Most students hold a logical understanding of medical ethics and medical ethics phenomena. As for the purpose of choosing the medical specialty, refer to Table $1.55 .1 \%$ of the students think it easy for employment, which is pragmatic. The employment is a direct consideration for students to study, after school beginning, aiming at the psychology, we need to strengthen the cultivation of professional ethics and professional quality as well as career edification.

TABLE I. Purposes OF StUdying MEdicine

\begin{tabular}{|l|l|l|l|l|}
\hline Option & $\begin{array}{c}\text { Number of } \\
\text { persons to } \\
\text { select } \\
\text { medical } \\
\text { specialty }\end{array}$ & $\begin{array}{c}\text { Number of } \\
\text { persons to } \\
\text { select non- } \\
\text { medical } \\
\text { specialty }\end{array}$ & $\begin{array}{c}\text { Number of } \\
\text { persons to } \\
\text { select } \\
\text { nursing } \\
\text { specialty }\end{array}$ & $\begin{array}{c}\text { Percen } \\
\text { tage }\end{array}$ \\
\hline $\begin{array}{l}\text { Life saving } \\
\text { and healing }\end{array}$ & 660 & 385 & 221 & $43.4 \%$ \\
\hline $\begin{array}{l}\text { Easy for } \\
\text { employmen } \\
\text { t }\end{array}$ & 808 & 531 & 267 & $55.1 \%$ \\
\hline $\begin{array}{l}\text { For more } \\
\text { honors and } \\
\text { benefits for } \\
\text { individuals } \\
\text { in the future }\end{array}$ & 20 & 18 & 6 & $1.5 \%$ \\
\hline
\end{tabular}

For items 7, 8, the students are surveyed for their understanding of attitudes to select clinic auxiliary examination for patients and the red envelops with money filled as gift and commission during diagnosis and treatment, refer to Table 2 for the results. The survey results show, $32.7 \%$ of students think it understandable to select examination items as more as possible, and $24.9 \%$ think it understandable to accept the red envelops and commission. 
TABLE II. ATtITUDES TO AUXILIARY EXAMINATIONS AND ACCEPTING RED ENVELOPS

\begin{tabular}{|l|l|l|l|l|}
\hline \multicolumn{1}{|c|}{ Item } & $\begin{array}{c}\text { Number of } \\
\text { students of } \\
\text { medical } \\
\text { specialty }\end{array}$ & $\begin{array}{c}\text { Number of } \\
\text { students of } \\
\text { non-medical } \\
\text { specialty }\end{array}$ & $\begin{array}{c}\text { Number of } \\
\text { students of } \\
\text { nursing } \\
\text { specialty }\end{array}$ & $\begin{array}{c}\text { Percent } \\
\text { age }\end{array}$ \\
\hline $\begin{array}{l}\text { Select those } \\
\text { necessary only }\end{array}$ & 1307 & 623 & 325 & $66.7 \%$ \\
\hline $\begin{array}{l}\text { Avoid medical } \\
\text { risks, select } \\
\text { examination } \\
\text { items as more } \\
\text { as possible, } \\
\text { which is } \\
\text { understandable }\end{array}$ & 162 & 307 & 167 & $32.7 \%$ \\
\hline $\begin{array}{l}\text { More items for } \\
\text { more income }\end{array}$ & 19 & 4 & 2 & \\
\hline Very averse & 1446 & 704 & 399 & \\
\hline Understandable & 39 & 221 & 88 & $24.9 \%$ \\
\hline Normal & 3 & 9 & 7 & $0.9 \%$ \\
\hline
\end{tabular}

B. Results Analysis of Tendencies to Behavior Selection before Real Problems

Items 11-20 are designed to expose the knowledge of medical students to the actual medical ethics and results selection, and the results are more satisfactory, however, for the selection of options where interest conflicts exist between patients and doctors, it is unsatisfactory, refer to Table 3 for details. Most students agree to obey the employers and how to be dedicated will need to be trained in the coming teaching.

TABLE III. RISK OF SELF HEALth When RESCUING PATIENTS

\begin{tabular}{|l|l|l|l|l|}
\hline \multicolumn{1}{|c|}{ Item } & $\begin{array}{l}\text { Number of } \\
\text { students of } \\
\text { medical } \\
\text { specialty }\end{array}$ & $\begin{array}{c}\text { Number of } \\
\text { students of } \\
\text { non-medical } \\
\text { specialty }\end{array}$ & $\begin{array}{l}\text { Number of } \\
\text { students of } \\
\text { nursing } \\
\text { specialty }\end{array}$ & $\begin{array}{c}\text { Percen } \\
\text { tage }\end{array}$ \\
\hline $\begin{array}{l}\text { Be the first to } \\
\text { rescue }\end{array}$ & 639 & 417 & 183 & $42.5 \%$ \\
\hline $\begin{array}{l}\text { Obey what the } \\
\text { employers } \\
\text { require }\end{array}$ & 734 & 454 & 273 & $50.1 \%$ \\
\hline $\begin{array}{l}\text { Consider family } \\
\text { members of my } \\
\text { own, a little } \\
\text { slower than } \\
\text { others to rescue }\end{array}$ & 115 & 63 & 38 & $7.4 \%$ \\
\hline
\end{tabular}

\section{RESUlTS ANALYSIS AND COUNTERMEASURES}

The overall results of the survey are satisfactory, but there are still more needed to improve in the understanding of medical ethics and the treatment of medical ethics problems. In recent years, the conflicts between doctors and patients have been reported frequently, main reasons are the stressing of professional knowledge but neglect of humanities in courses of the medical students, besides, medical workers have to bear high-strength work load and long term work pressure, which finally cause sharp doctorpatient conflicts.

The medical ethics education can be done by stages and grades, and the survey shows, low-grade students hold lower self evaluation over communication skills with patients, who are suggested to face patients early such as participation in medical service at community health service stations and clinic activities so as to improve abilities and skills of communication in practice. The high grade students may face more patients via internship and the guidance of doctors. When facing with special cases, the students shall be encouraged to try to deal with it by themselves, read more medical books, understand the diseases and broaden thinking so that students can have their abilities of communication and problem treatment exercised.

For a long time we have been valuing medical students especially those of clinical medicine, and elective courses such as humanities are set in the course design; however, there are almost no courses relative to the humanistic quality training for students of nursing who face patients directly. The survey results also show that the medical ethics of nursing students is even more worrying. Traditionally, doctors are the most important in the relationship between doctors and patients, and nurses just offer assistance, actually, the work of nurses is much closer to patients, which needs more patience and noble quality. It is necessary to separately set courses such as Doctor-Patient Communication, Medical Work and Ethics. In addition, regularly make medical lectures about humanities, which can not only help medical students get medical humanity knowledge through various channels but also enhance the professional quality of medical students. In the meantime, create an incorruptible culture environment in campus such as slogans, promotion of advanced stores of incorruptible workers, which can not only bring good effect potentially but also improve the medical ethics education.

\section{REFERENCES}

[1] Liang Qian, Chen Maohuai, et al, Status Quo of Medical Ethics under New Situations and Thought about Countermeasures in Education [J] Chinese Medical Ethics, 2017, 1 (30): 53-57.

[2] Yang Lingli, On Connotation of Medical Ethics and Goal of Training Contemporary Medical Students in Medical Ethics [J] Journal of Liaoning Medical University (Social Science Edition), 2015,13(1) : 24-27.

[3] Jiao Guangyuan, Zhou Lingwei, Sun Yingwei, et al, Application of Service-Learning Education Mode in Medical Ethics Education of Medical Students.. 